ABDIMAS: Jurnal Pengabdian Masyarakat Universitas Merdeka Malang
Vol.6(1) February 2021, 121-132
U-ISSN: 2721-138X e-ISSN: 2548-7159
Uttp://jurnal.unmer.ac.id/index.php/jpkm

\title{
Peningkatan Produksi dan Pendapatan Petani Jagung Pulut melalui Aplikasi Pupuk Organik Abu Sabut Kelapa
}

\author{
Marianne Reynelda Mamondol', Silvany Annatje Taariwuan ${ }^{2}$ \\ ${ }^{1}$ Departemen Agribisnis Fakultas Pertanian, ${ }^{2}$ Departemen Studi Manajemen Fakultas Ekonomi, \\ Universitas Kristen Tentena \\ Jl. Torulemba No.21 Tentena, Poso, 94663, Indonesia
}

\section{ARTICLE INFO}

Received: 2020-11-04

Revised: 2020-12-16

Accepted: 2021-01-26

Keywords:

Coconut ash, Organic fertilizer, Partner, Waxy corn

\section{ABSTRACT}

This community service was carried out at Poso Regency in June to November 2019. Its purpose was to provide training and assistance to partner in utilizing and processing coconut fiber as agricultural waste into organic fertilizer of ash to be applied to waxy corn crop. The method of activity includes: (1) Explanation regarding the process of making organic fertilizer with raw materials of coconut fiber wastes, and economic aspect of utilizing coconut ash organic fertilizer; (2) Production activity in the form of the coconut ash organic fertilizer processing training, the fertilizer application to crop, and profit farming analysis to measure turnover increasing; (3) Partner assistance during the training and productions processes. Partner consists of farmer who belongs to the category of economically productive. Results demonstrate that the program implementation has given improvement to technical and economic achievements of partner's farming. The improvement of waxy corn production was from 0.90 tonnes/hectare to 3.912 tonnes/hectare, whereas the increased farm profits was from IDR 2,600,000/ha/planting season to IDR 16,066,000/ha/planting season. A high level of partner's satisfaction to cooperation and activity outcome on partner's productive business was an incentive to continue adopting coconut ash organic fertilizer technology in his subsequent farming activities.

(C) 2021 Published by University of Merdeka Malang. This is an open access article distributed under the CC BY-SA 4.0 license

(https://creativecommons.org/licenses/by-sa/4.0/)

How to cite: Mamondol, M. R., \& Taariwuan, S. A. (2021). Peningkatan Produksi dan Pendapatan Petani Jagung Pulut melalui Aplikasi Pupuk Organik Abu Sabut Kelapa. Abdimas: Jurnal Pengabdian Masyarakat Universitas Merdeka Malang, 6(1), 121-132. https://doi.org/10.26905/abdimas.v6i1.4988

\section{PENDAHULUAN}

Dewasa ini permintaan terhadap jagung pulut atau jagung ketan (Zea mays ceratina Kulesh) semakin meningkat, baik oleh masyarakat maupun industri. Jagung pulut dapat dikonsumsi dalam berbagai bentuk makanan olahan oleh masyarakat, dan dapat pula dimanfaatkan sebagai bahan baku pembuatan tepung jagung atau pakan ikan oleh industri (Tengah et al., 2017), sehingga mendorong terciptanya diversifikasi bahan pangan dan peningkatan swasembada pangan (Dahlan et al., 2013). Daerah Kabupaten Poso merupakan penghasil tanaman pangan seperti padi dan jagung. Tanaman jagung umumnya dibudidayakan di sawah setelah penanaman padi, sebagai tanaman alterntif yang 
ABDIMAS: Jurnal Pengabdian Masyarakat Universitas Merdeka Malang Volume 6, No. 1, February 2021: 121-132

diusahakan saat ketersediaan air berkurang karena curah hujan yang kurang, atau ditanam di lahan kering milik petani. Varietas jagung yang banyak diusahakan oleh petani ialah jagung pulut atau jagung ketan, karena di samping merupakan bahan pangan yang digemari masyarakat juga menjadi komoditas yang dapat dipasarkan dan memberikan penghasilan bagi petani.

Jagung pulut merupakan salah satu jenis jagung lokal yang berasal dari Sulawesi Selatan (Juhaeti et al., 2013). Jagung pulut memiliki keunggulan berupa teksturnya yang lebih empuk dan lembut karena kandungan amilopektin sebesar lebih dari $80 \%$ pada biji jagung. Kandungan amilopektin inilah yang memberikan keunikan pada jagung pulut berupa sensasi lengket dan kenyal seperti ketan (Setyowati \& Utami, 2013). Permintaan pasar jagung pulut terus mengalami peningkatan karena tingginya minat masyarakat terhadap jagung pulut, terutama konsumen yang menggemari produk pangan tradisional (Suarni et al., 2019). Akan tetapi kenaikan permintaan ini tidak bisa diimbangi dengan produksi. Menurut (Suarni, 2013), jagung pulut lokal Sulawesi umumnya memiliki produktivitas yang hanya mencapai 2 hingga 2,5 ton/ha, sementara potensi hasil bisa mencapai 8,09 ton/ha. Di Kabupaten Poso pada tahun 2012 produksi jagung pulut hanya mencapai 3.731,2 ton, lebih rendah jika dibandingkan dengan produksi di tingkat Provinsi Sulawesi Tengah sebesar 440.308 ton (BPS Poso, 2013).

Beberapa hasil penelitian pendahuluan menunjukkan bahwa rendahnya produksi jagung pulut di tingkat petani terutama disebabkan karena kurang optimalnya pemupukan yang dilakukan oleh petani pada tanaman, di mana tanaman jagung pulut umumnya diusahakan pada lahan-lahan kering dengan tingkat kesuburan rendah (Dulur et al., 2019; Bunyamin et al., 2015). Di samping itu sebagian besar petani belum memahami teknik budidaya tanaman jagung pulut yang tepat, termasuk manfaat pemberian pupuk pada tanaman (Saprianto et al., 2021). Hasil penelitian dari Malawat (2015) menunjukkan bahwa rendahnya produktivitas jagung pulut disebabkan karena petani masih menggunakan varietas lokal dengan teknik budidaya yang kurang intensif seperti pengendalian organisme pengganggu tanaman yang belum optimal, tanpa olah tanah, dan tanpa pemupukan.

Mitra dalam kegiatan pengabdian kepada masyarakat ini yaitu Bapak Bino Burengge, berdomisili di Desa Buyumpondoli, Kecamatan Pamona Puselemba, Kabupaten Poso yang berjarak 1 km sebelah barat lokasi Universitas Kristen Tentena. Mitra merupakan petani yang memiliki lahan kering seluas 0,5 ha yang ditanami tanaman palawija seperti kedelai, kacang tanah, dan jagung pulut. Usaha tani jagung pulut merupakan salah satu sumber pendapatan utama bagi mitra karena pengusahaannya yang bersifat intensif dan produk hasil usahatani yang selalu dipasok ke pasar. Dengan demikian mitra merupakan masyarakat yang produktif secara ekonomi dengan skala usaha mikro.

Bagi mitra, usaha tani jagung pulut lebih prospektif dibandingkan tanaman palawija lainnya karena harga jagung pulut yang relatif lebih stabil di pasar. Bahkan pasokan jagung pulut sering tidak dapat memenuhi permintaan pasar, karena jagung pulut merupakan bahan pangan yang banyak dikonsumsi masyarakat dalam berbagai macam bentuk makanan olahan. Karena itu, pengembangan usaha tani jagung pulut merupakan peluang bisnis yang mampu memberikan keuntungan pada mitra.

Akan tetapi usaha tani jagung pulut sering menemui kendala, terutama yang berkaitan dengan masalah pemupukan. Kebutuhan pupuk yang meningkat tidak diimbangi dengan ketersediaan pupuk di pasaran, sehingga berpengaruh terhadap harga pupuk. Tidak jarang mitra menghadapi kelangkaan 


\section{Peningkatan Produksi dan Pendapatan Petani Jagung Pulut melalui Aplikasi Pupuk Organik Abu Sabut Kelapa \\ Marianne Reynelda Mamondol, Silvany Annatje Taariwuan}

pupuk, dan kalau pun ada harganya tinggi. Kendala ini menyebabkan mitra tidak melakukan pemupukan pada tanaman dan hanya mengharapkan pasokan unsur hara dari tanah. Dampaknya ialah pada produksi jagung pulut yang rendah, rata-rata hanya mencapai 0,75-0,90 ton/ha dengan kualitas yang rendah pula seperti tongkol yang berukuran relatif kecil dan biji yang tidak menempel secara utuh pada tongkol. Jagung berkualitas rendah biasanya tidak dijual ke pasar oleh mitra. Sementara itu, pengetahuan mitra mengenai pemanfaatan limbah pertanian sebagai sumber pupuk organik sangat minim. Padahal beberapa limbah pertanian bisa diolah menjadi pupuk organik yang sangat potensial untuk digunakan pada tanaman jagung pulut.

Jagung pulut memiliki karakteristik citarasa yang lebih gurih, lembut, dan pulen. Hal ini disebabkan karena kandungan amilopektin di dalam biji jagung pulut yang mencapai $90-100 \%$ (Suarni, 2009). Penelitian yang dilakukan oleh (Maruapey \& Faesal, 2010) menunjukkan bahwa penggunaan pupuk $\mathrm{KCl}$ dapat meningkatkan produksi dan kadar amilopektin di dalam biji jagung pulut. Dengan demikian dapat diketahui adanya hubungan antara unsur hara kalium (K) dengan pertumbuhan, hasil, dan kualitas jagung pulut. Selain dari pupuk anorganik, sumber K yang lain ialah bahan-bahan organik yang berasal dari alam. Terdapat bahan-bahan alami yang kaya akan kandungan unsur $\mathrm{K}$, di antaranya ialah sabut kelapa (Nurhayati et al., 2011). Kabupaten Poso merupakan daerah penghasil komoditas kelapa, akan tetapi sabut kelapa umumnya masih merupakan limbah pertanian yang belum banyak diketahui manfaatnya oleh masyarakat. Padahal sabut kelapa dapat pula diolah menjadi bahan baku pembuatan pupuk organik yang dapat diaplikasikan pada tanaman budidaya. Dalam Rizki \& Agustini (2018) melaporkan bahwa abu sabut kelapa memiliki kandungan $\mathrm{K}$ sebesar 20 hingga 30\%. Tingginya kadar $\mathrm{K}$ tersebut mengindikasikan bahwa abu sabut kelapa dapat dimanfaatkan sebagai sumber nutrisi dalam budidaya tanaman. Manfaat lainnya dari abu sabut kelapa ialah mampu meretensi kadar air tanah dan menciptakan lingkungan yang kondusif bagi mikroorganisme tanah (Muchtar et al., 2018).

Hasil penelitian Mamondol \& Bunga (2017) memperlihatkan bahwa penggunaan abu sabut kelapa berpengaruh secara signifikan terhadap beberapa parameter hasil dan kualitas jagung pulut. Dosis pupuk sebesar 0,75 ton/ha memberikan rata-rata bobot per tongkol dengan klobot sebesar 165,33 gr, rata-rata produksi jagung pulut dengan klobot sebesar 6,75 ton/ha, dan rata-rata produksi jagung pulut tanpa klobot sebesar 5,06 ton/ha. Nilai-nilai tersebut tidak berbeda nyata dengan yang diperoleh pada penggunaan pupuk dengan dosis yang lebih tinggi pada penelitian tersebut, yaitu dosis 3,75 ton/ha dan 4,50 ton/ha.

Oleh karena itu, diperlukan adanya introduksi dan pelatihan bagi mitra untuk membuat pupuk organik dari bahan sabut kelapa serta mengaplikasikan pupuk organik tersebut pada tanaman jagung pulut. Hal ini dimaksudkan agar mitra dapat memanfaatkan bahan organik lokal yang tersedia di sekitarnya menjadi input yang berpotensi meningkatkan produksi dan kualitas produk tanaman. Melalui kegiatan pengabdian kepada masyarakat, tujuan-tujuan yang hendak dicapai ialah sebagai berikut: (1) Menentukan cara yang dapat ditempuh mitra untuk meningkatkan keuntungan usaha tani jagung pulut; (2) Merumuskan cara meningkatkan produksi dan kualitas jagung pulut yang dibudidayakan oleh mitra; (3) Menemukan cara mengatasi kendala kelangkaan pupuk di pasaran; (4) Melatih mitra membuat pupuk organik dari bahan baku lokal yang dapat dimanfaatkan pada tanaman; (5) Melatih 
ABDIMAS: Jurnal Pengabdian Masyarakat Universitas Merdeka Malang

Volume 6, No. 1, February 2021: 121-132

mitra menggunakan pupuk organik berbahan baku sabut kelapa pada tanaman jagung pulut; (6) Melatih mitra untuk memanfaatkan pupuk organik abu sabut kelapa secara berkelanjutan.

Permasalahan prioritas yang dihadapi oleh mitra memerlukan solusi yang konkrit dan sesuai dengan kebutuhan mitra. Adapun solusi-solusi yang ditawarkan untuk pelaksanaan program dan disetujui oleh mitra ialah sebagai berikut: (1) Peningkatan keuntungan usaha tani dapat ditempuh melalui dua alternatif, yaitu peningkatan produksi dan kualitas jagung pulut atau minimisasi biaya produksi usaha tani jagung pulut. Mitra menginginkan peningkatan keuntungan dari usaha tani jagung pulut untuk peningkatan kesejahteraan keluarga dan mendapatkan modal bagi kegiatan usaha tani pada periode berikutnya. Karena itu alternatif pertama yang ditawarkan kepada mitra ialah meningkatkan produksi dan kualitas jagung pulut. Tanpa penggunaan pupuk, produksi jagung pulut mitra paling banyak hanya mencapai 0,90 ton/ha. Apabila produksi jagung pulut dapat ditingkatkan di atas 0,90 ton/ha dengan asumsi harga saat survei sebesar Rp8.000/kg tidak mengalami penurunan maka keuntungan yang diperoleh mitra dari usaha tani jagung pulut akan meningkat. Alternatif kedua berupa minimisasi biaya produksi dapat pula ditempuh dengan mengefisienkan penggunaan faktor-faktor produksi berupa modal dan tenaga kerja. Dengan mempertimbangkan bahwa jumlah keuntungan secara fisik akan lebih besar diperoleh apabila produk yang dipasok ke pasar lebih besar, maka disepakati bersama dengan mitra bahwa alternatif yang dipilih ialah peningkatan produksi dan kualitas jagung pulut; (2) Peningkatan produksi dan kualitas jagung pulut pada dasarnya ditentukan oleh lebih dari satu variabel, akan tetapi dalam konteks permasalahan yang dihadapi mitra, upaya peningkatan produksi dan kualitas tanaman dapat dilakukan melalui pemberian pupuk pada tanaman dalam dosis yang tepat sesuai kebutuhan tanaman. Menurut Maruapey \& Faesal (2010), dosis pupuk $\mathrm{KCl}$ antara $75-100 \mathrm{~kg} / \mathrm{ha}$ meningkatkan tinggi tanaman, kadar amilopektin, dan umur berbunga tercepat pada tanaman jagung pulut. Hasil penelitian ini mengindikasikan bahwa unsur hara kalium berperan penting dalam meningkatkan hasil dan kualitas jagung pulut; (3) Kendala kelangkaan pupuk $\mathrm{KCl}$ di pasaran dapat diatasi dengan pemanfaatan bahan-bahan yang tersedia di alam untuk diproses menjadi pupuk yang dapat diaplikasikan pada tanaman. Tanaman kelapa menghasilkan limbah berupa sabut kelapa dalam jumlah yang besar, dan bahan tersebut dapat dijadikan sebagai bahan baku lokal pupuk organik. Penelitian sebelumnya yang dilaksanakan oleh Mamondol \& Bunga (2017) memperlihatkan pengaruh yang positif dan signifikan dari pupuk organik abu sabut kelapa terhadap hasil dan kualitas jagung pulut. Unsur kalium pada pupuk abu sabut kelapa menyebabkan pengisian biji dengan karbohidrat semakin besar, sehingga ukuran biji bertambah besar, tongkol terisi padat dengan biji, dan bobot tongkol semakin bertambah; (4) Terdapat beberapa metode pembuatan pupuk organik dengan menggunakan bahan baku sabut kelapa. Metode yang dapat diterapkan di antaranya ialah pembakaran sabut kelapa menjadi abu. Pengambilan senyawa $\mathrm{K}$ dari limbah pertanian dilakukan menjadi abu sehingga garam-garam organik yang terkandung di dalamnya berubah menjadi kalium karbonat (Maesaroh et al., 2014). Pembakaran sabut kelapa menjadi abu membutuhkan waktu yang lebih singkat, di mana abu yang terbentuk dari hasil pembakaran selama 2-3 hari dapat digunakan sebagai pupuk bagi tanaman; (5) Pupuk organik abu sabut kelapa digunakan dengan cara dicampurkan pada tanah sesuai dosis yang telah ditetapkan. Pada kegiatan ini digunakan pupuk abu sabut kelapa dengan dosis sebesar 0,75 ton/ha sebagaimana yang diterapkan pada penelitian Mamondol \& Bunga (2017); (6) Agar pemanfaatan pupuk organik abu sabut kelapa dapat digunakan secara berkelanjutan oleh mitra maka 


\section{Peningkatan Produksi dan Pendapatan Petani Jagung Pulut melalui Aplikasi Pupuk Organik Abu Sabut Kelapa}

Marianne Reynelda Mamondol, Silvany Annatje Taariwuan

kegiatan pengabdian ini harus memberikan hasil yang signifikan dan target peningkatan keuntungan usaha tani jagung pulut sebagaimana yang ditetapkan bersama dengan mitra dapat tercapai. Untuk itu akan dilaksanakan pemberdayaan bagi mitra dengan kegiatan-kegiatan yang meliputi pelatihan dan pendampingan selama proses pengolahan sabut kelapa menjadi pupuk organik dan pengaplikasiannya pada tanaman jagung pulut. Seluruh tahapan kegiatan direncanakan berlangsung selama 6 bulan sesuai jangka waktu pelaksanaan kegiatan pengabdian kepada masyarakat.

\section{METODE}

Metode pelaksanaan kegiatan dilakukan melalui aspek pemberdayaan mitra yang meliputi berbagai kegiatan.

\section{Penjelasan Kegiatan kepada Mitra}

Materi-materi yang diberikan kepada mitra ialah sebagai berikut: (1) Permasalahan limbah pertanian, jenis-jenis limbah pertanian, permasalahan bahan organik tanah, peranan bahan organik dalam tanah, dan sumber-sumber bahan organik; (2) Penggunaan abu sabut kelapa sebagai pupuk organik pada tanaman jagung pulut, yaitu sebagai substitusi pupuk $\mathrm{KCl}$ anorganik. Kepada mitra akan dijelaskan metode pembakaran yang menghasilkan abu dengan kualitas yang baik; (3) Aspek ekonomis penggunaan pupuk organik abu sabut kelapa. Kepada mitra akan diperlihatkan analisis ekonomi usaha tani berupa perhitungan laba usaha tani yang akan diperoleh apabila mitra menggunakan input dengan harga yang relatif lebih murah.

\section{Pelatihan bagi Mitra}

Setelah mitra memahami desain kegiatan yang akan dilakukan, maka selanjutnya dilaksanakan kegiatan pelatihan pembuatan pupuk organik abu sabut kelapa serta pengaplikasiannya pada pertanaman jagung pulut. Mitra diberikan kesempatan mengerjakan secara langsung pembuatan pupuk organik di bawah bimbingan instruktur. Mitra diperkenalkan dengan jenis-jenis bahan yang diperlukan, persiapan bahan, dan proses pencampuran bahan. Selama proses pembuatan pupuk, mitra dibimbing untuk mengerjakan setiap tahapan proses secara teknis dengan benar untuk menghasilkan produk pupuk yang bermutu tinggi.

Setelah pembuatan pupuk selesai, mitra diberikan petunjuk pengaplikasian pupuk pada tanaman jagung pulut, terutama pengukuran dosis dan cara pemberian pupuk pada tanaman. Setelah panen, mitra dibimbing untuk melakukan analisis keuntungan usaha tani untuk mengukur peningkatan omzet yang dicapai.

\section{Pendampingan Mitra}

Pendampingan bagi mitra berlangsung selama proses pembuatan pupuk organik, pengaplikasian pupuk pada tanaman, panen, dan perhitungan keuntungan usaha tani. Bagi mitra disiapkan materi- 
ABDIMAS: Jurnal Pengabdian Masyarakat Universitas Merdeka Malang

Volume 6, No. 1, February 2021: 121-132

materi tertulis untuk dapat dipelajari secara intensif. Setiap permasalahan atau pertanyaan mitra terkait dengan kegiatan pengabdian dipecahkan secara bersama-sama sehingga pemahaman mitra diharapkan semakin meningkat.

Partisipasi mitra dalam pelaksanaan program ialah sebagai berikut: (1) Sebagai kontributor ide, pemikiran, pertimbangan, dan informasi terkait hal-hal teknis pelaksanaan program; (2) Sebagai penanggung jawab ketersediaan bahan dan alat penelitian yang tersedia di lingkungan sekitarnya; (3) Sebagai penyedia lokasi untuk pembuatan pupuk maupun penanaman jagung pulut; (4) Sebagai penanggung jawab pemeliharaan tanaman jagung pulut hingga saat panen; (5) Sebagai sumber informasi bagi petani lainnya mengenai pemanfaatan bahan limbah pertanian lokal menjadi pupuk organik bagi tanaman.

Evaluasi pelaksanaan program dilakukan setiap akhir bulan berjalan dengan melakukan perbandingan antara kemajuan yang telah dicapai dengan perencanaan awal kegiatan. Evaluasi pelaksanaan program meliputi kegiatan teknis di lapangan dan pengelolaan dana kegiatan pengabdian. Evaluasi mengacu pada laporan harian, mingguan, dan bulanan. Setiap kemajuan dan kendala yang dihadapi selama pelaksanaan program dikoordinasikan bersama oleh tim.

Keberlanjutan program setelah kegiatan pengabdian selesai dilaksanakan diharapkan terutama berasal dari keinginan atau permintaan masyarakat setempat. Untuk itu diupayakan agar kegiatan pegabdian ini memberikan hasil yang optimal dan signifikan terutama dari segi kuantitas dan kualitas produksi tanaman sehingga menarik minat masyarakat untuk menerapkannya. Kualitas pupuk yang baik juga menjadi target yang ingin dicapai sehingga pemanfaatannya pada tanaman bisa memberikan pengaruh yang signifikan. Dengan demikian, manfaat pupuk organik abu sabut kelapa ini dapat dirasakan oleh masyarakat, dan keinginan masyarakat untuk terus memproduksinya dapat tetap berkelanjutan.

\section{HASIL DAN PEMBAHASAN}

\section{Hasil yang Dicapai}

\section{Pemahaman mitra terhadap kegiatan pengabdian}

Kepada mitra telah dijelaskan mengenai pemanfaatan limbah pertanian menjadi produk yang bermanfaat dan memiliki nilai ekonomi, di antaranya sabut kelapa yang dapat diolah menjadi pupuk organik untuk tanaman jagung pulut. Mitra telah memahami bahwa pupuk organik abu sabut kelapa mengandung unsur hara kalium yang cukup tinggi, bermanfaat bagi peningkatan produksi dan kualitas jagung pulut, serta dapat menjadi alternatif bagi pupuk $\mathrm{KCl}$ anorganik yang sering tidak tersedia di pasar. Mitra memahami pula bahwa penggunaan pupuk organik dalam usaha tani jagung pulut dapat mendukung ketersediaan bahan-bahan organik bagi tanah, meningkatkan kesuburan tanah, menghasilkan produk-produk pangan yang aman untuk dikonsumsi, dan mendukung terlaksananya aktivitas pertanian yang ramah lingkungan dan berkelanjutan. Pemahaman mitra sangat diperlukan guna menunjang terlaksananya kegiatan pengabdian selanjutnya, dikarenakan mitra dapat mengerti prosedur dan manfaat kegiatan dan memberikan respon yang positif terhadapnya. 


\section{Peningkatan Produksi dan Pendapatan Petani Jagung Pulut melalui Aplikasi Pupuk Organik Abu Sabut Kelapa}

Marianne Reynelda Mamondol, Silvany Annatje Taariwuan

\section{Pelaksanaan pembuatan pupuk organik abu sabut kelapa bersama dengan mitra}

Mitra telah menerima penjelasan mengenai bahan-bahan baku yang dibutuhkan, alat-alat yang digunakan, dan prosedur kerja yang harus dilalui dalam pembuatan pupuk organik abu sabut kelapa. Mitra juga telah mengikuti langsung proses pembuatan pupuk organik mulai dari tahap persiapan, proses peembakaran, pendinginan, dan penimbangan pupuk sebelum diaplikasikan pada tanaman. Pengetahuan dan pengalaman mitra dalam mengikuti proses pembuatan pupuk sangat dibutuhkan agar nantinya mitra dapat menggunakan pengetahuan dan pengalaman tersebut dalam membuat pupuk organik secara mandiri pada waktu mendatang.

\section{Proses pengaplikasian pupuk dan penanaman benih jagung pulut}

Mitra telah ikut serta dalam proses pengaplikasian pupuk sebelum penanaman benih jagung pulut. Lahan milik mitra yang dijadikan sebagai lokasi kegiatan telah diolah dengan traktor sebanyak 2 kali dan dibuatkan bedengan-bedengan untuk penanaman benih. Kegiatan aplikasi pupuk dilakukan 3 hari sebelum penanaman, di mana pupuk ditebarkan secara merata pada bedeng lalu dicampurkan dengan tanah.

\section{Pendampingan mitra selama pertumbuhan, produksi hingga panen}

Pendampingan terhadap mitra dilakukan selama berlangsungnya pertumbuhan, produksi hingga panen tanaman jagung pulut. Jagung pulut dipanen setelah mencapai umur 70 hari setelah tanam (HST). Selama periode waktu tersebut, kepada mitra diberikan penjelasan mengenai aspek teknis produksi tanaman jagung pulut terutama yang berkaitan dengan pemeliharaan tanaman serta pencegahan dan penanggulangan hama, penyakit, dan gulma. Selain itu juga diberikan penjelasan mengenai aspek ekonomi budidaya jagung pulut dengan menggunakan pupuk organik. Dengan demikian diharapkan mitra dapat memahami kelayakan teknis dan ekonomis penggunaan pupuk organik abu sabut kelapa terhadap usaha tani jagung pulut yang dimiliki mitra.

\section{Capaian Teknis Kegiatan Pengabdian kepada Masyarakat}

Panen tanaman jagung pulut dilakukan secara ubinan dengan mengambil sampel sebanyak 5 petak percontohan. Jagung pulut yang berasal dari setiap petak berukuran $15 \mathrm{~m} \times 1 \mathrm{~m}$ seluruhnya diambil dan ditimbang tanpa klobot, kemudian hasil penimbangan dikonversi ke satuan ton/ha. Hasil penimbangan dan konversi diperlihatkan dalam Tabel 1.

Tabel 1. Hasil penimbangan jagung pulut

\begin{tabular}{ccc}
\hline Petak Contoh & Hasil (kg/petak) & Hasil (ton/ha) \\
\hline 1 & 6,110 & 4,073 \\
2 & 5,300 & 3,533 \\
3 & 6,250 & 4,167 \\
4 & 5,320 & 3,547 \\
5 & 6,360 & 4,240 \\
\hline Rata-rata & 5,868 & 3,912 \\
\hline
\end{tabular}


ABDIMAS: Jurnal Pengabdian Masyarakat Universitas Merdeka Malang

Volume 6, No. 1, February 2021: 121-132

Berdasarkan tabel dapat dilihat bahwa rata-rata produksi jagung pulut ialah sebesar $5,868 \mathrm{~kg} /$ petak atau 3,912 ton/ha. Jika dibandingkan dengan produksi maksimum yang diperoleh mitra sebelum menerapkan pemupukan organik yaitu sebesar 0,90 ton/ha maka terjadi kenaikan produksi jagung pulut sebesar $334,67 \%$. Secara visual, jagung pulut yang dihasilkan juga lebih besar ukurannya dan memiliki rasa yang lebih manis dan pulen.

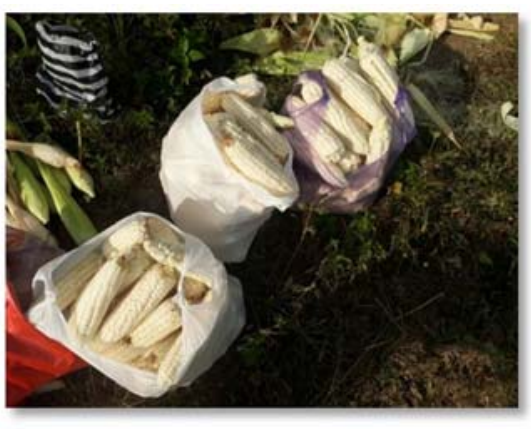

Gambar 1. Jagung pulut hasil panen

Walaupun demikian, produksi jagung pulut belum dapat mencapai produktivitas potensialnya yaitu sebesar 8,09 ton/ha. Hal ini disebabkan karena musim kemarau berkepanjangan yang melanda sebagian besar wilayah Indonesia termasuk Kabupaten Poso pada saat pelaksanaan kegiatan pengabdian masyarakat, yang mengakibatkan para petani termasuk mitra kegiatan ini mengalami kesulitan untuk memperoleh air bagi pengairan sawah dan ladangnya. Pada dasarnya tanaman jagung pulut bersifat toleran terhadap kekeringan (Wawo et al., 2019), namun kekeringan dalam jangka waktu yang cukup lama dapat mempengaruhi proses pembentukan dan pengisian tongkol pada tanaman. Pertumbuhan tanaman jagung pulut milik mitra juga dipengaruhi oleh kurangnya ketersediaan air, sehingga pada umumnya dari satu tanaman jagung pulut hanya bisa diperoleh satu tongkol jagung. Padahal apabila ketersediaan air mencukupi, maka dapat terbentuk lebih dari satu tongkol pada tanaman.

\section{Capaian Ekonomis Kegiatan Pengabdian kepada Masyarakat}

Capaian ekonomis kegiatan pengabdian diukur dari peningkatan omzet atau pendapatan usaha tani jagung pulut mitra. Pada Tabel 2 dan Tabel 3 ditampilkan analisis pendapatan usaha tani jagung pulut mitra sebelum dan sesudah penerapan penggunaan pupuk organik abu sabut kelapa pada tanaman. Tabel 2 memperlihatkan bahwa sebelum melakukan pemupukan organik, dengan produksi maksimal jagung pulut sebesar 0,90 ton/ha dan harga jual jagung pulut Rp8.000/kg, penerimaan usaha tani jagung pulut ialah sebesar Rp7.200.000. Biaya produksi yang dikeluarkan sebesar Rp4.600.000 yang meliputi pembayaran pajak lahan, biaya tenaga kerja, dan biaya pembelian benih jagung pulut varietas lokal. Pendapatan usaha tani jagung pulut mitra sebelum aplikasi pemupukan pada tanaman ialah sebesar Rp2.600.000/ha/musim tanam. Tanpa melakukan pemupukan dan pemeliharaan pada tanaman berupa pengendalian hama dan penyakit maka produksi dan kualitas produk yang diperoleh sangat rendah yang berdampak pada perolehan pendapatan yang rendah pula. 


\section{Peningkatan Produksi dan Pendapatan Petani Jagung Pulut melalui Aplikasi Pupuk Organik Abu Sabut Kelapa}

Marianne Reynelda Mamondol, Silvany Annatje Taariwuan

Tabel 2. Analisis pendapatan usaha tani jagung pulut sebelum penerapan pemupukan organik abu sabut kelapa (Rp/ha/musim tanam)

\begin{tabular}{|c|c|c|}
\hline Komponen & Satuan & $\mathbf{R p}$ \\
\hline Penerimaan & 0,90 ton $\times \mathrm{Rp} 8.000 / \mathrm{kg}$ & 7.200 .000 \\
\hline Biaya Produksi & 1 ha & \\
\hline 1. Pajak lahan & Ina & 150.000, - \\
\hline 2. Biaya tenaga kerja: & 8 orang $\times 2$ hari & \\
\hline $\begin{array}{l}\text { a. Pengolahan tanah } \\
\text { b. Penanaman benih }\end{array}$ & 8 orang $x 1$ hari & $\begin{array}{l}2.000 .000,- \\
1.200 .000,-\end{array}$ \\
\hline c. Pemupukan & - & - \\
\hline d. Pengendalian hama/penyakit & & \\
\hline $\begin{array}{ll} & \text { e. Panen } \\
\text { 3. Biaya pupuk }\end{array}$ & 8 orang $\times 1$ hari & 1200.000 - \\
\hline 4. Biaya pestisida & - & $1.200 .000_{1}$ \\
\hline 5. Biaya benih varietas lokal & $5 \mathrm{~kg}$ & 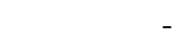 \\
\hline 6. Jumlah biaya produksi & $5 \mathrm{~kg}$ & $\begin{array}{r}50.000,- \\
4.600 .000\end{array}$ \\
\hline Pendapatan (Penerimaan-Biaya Produksi) & & 2.600 .000 \\
\hline
\end{tabular}

Pada Tabel 3 dapat dilihat bahwa sesudah melakukan pemupukan organik abu sabut kelapa terjadi peningkatan produksi yang cukup signifikan yang berdampak pada peningkatan pendapatan usaha tani. Produksi jagung pulut sebesar 3,912 ton/ha dan harga jual jagung pulut Rp8.000/kg memberikan penerimaan sebesar Rp31.296.000. Biaya produksi yang dikeluarkan mengalami kenaikan menjadi sebesar Rp15.230.000 karena adanya tambahan biaya tenaga kerja untuk pengolahan tanah dengan traktor, pemupukan, dan pengendalian hama/penyakit tanaman, biaya pengadaan pupuk, pembelian pestisida, dan penggunaan benih varietas unggul.

Pendapatan usaha tani sesudah melakukan pemupukan mencapai Rp16.066.000/ha/musim tanam atau meningkat sebesar 517,923\% dibandingkan pendapatan usahatani sebelum dilakukannya pemupukan pada tanaman. Peningkatan pendapatan memungkinkan mitra untuk melakukan budidaya tanaman secara lebih intensif sehingga produksi jagung pulut yang dihasilkan akan meningkat kualitasnya.

Pada Tabel 3 dapat dilihat bahwa sesudah melakukan pemupukan organik abu sabut kelapa terjadi peningkatan produksi yang cukup signifikan yang berdampak pada peningkatan pendapatan usaha tani. Pendapatan usaha tani sesudah melakukan pemupukan mencapai Rp16.066.000/ha/musim tanam atau meningkat sebesar 517,923\% dibandingkan pendapatan usaha tani sebelum dilakukannya pemupukan pada tanaman. Peningkatan pendapatan memungkinkan mitra untuk melakukan budidaya tanaman secara lebih intensif sehingga produksi jagung pulut yang dihasilkan akan meningkat kualitasnya. 
ABDIMAS: Jurnal Pengabdian Masyarakat Universitas Merdeka Malang

Volume 6, No. 1, February 2021: 121-132

Tabel 3. Analisis pendapatan usaha tani jagung pulut sesudah penerapan pemupukan organik abu sabut kelapa (Rp/ha/musim tanam)

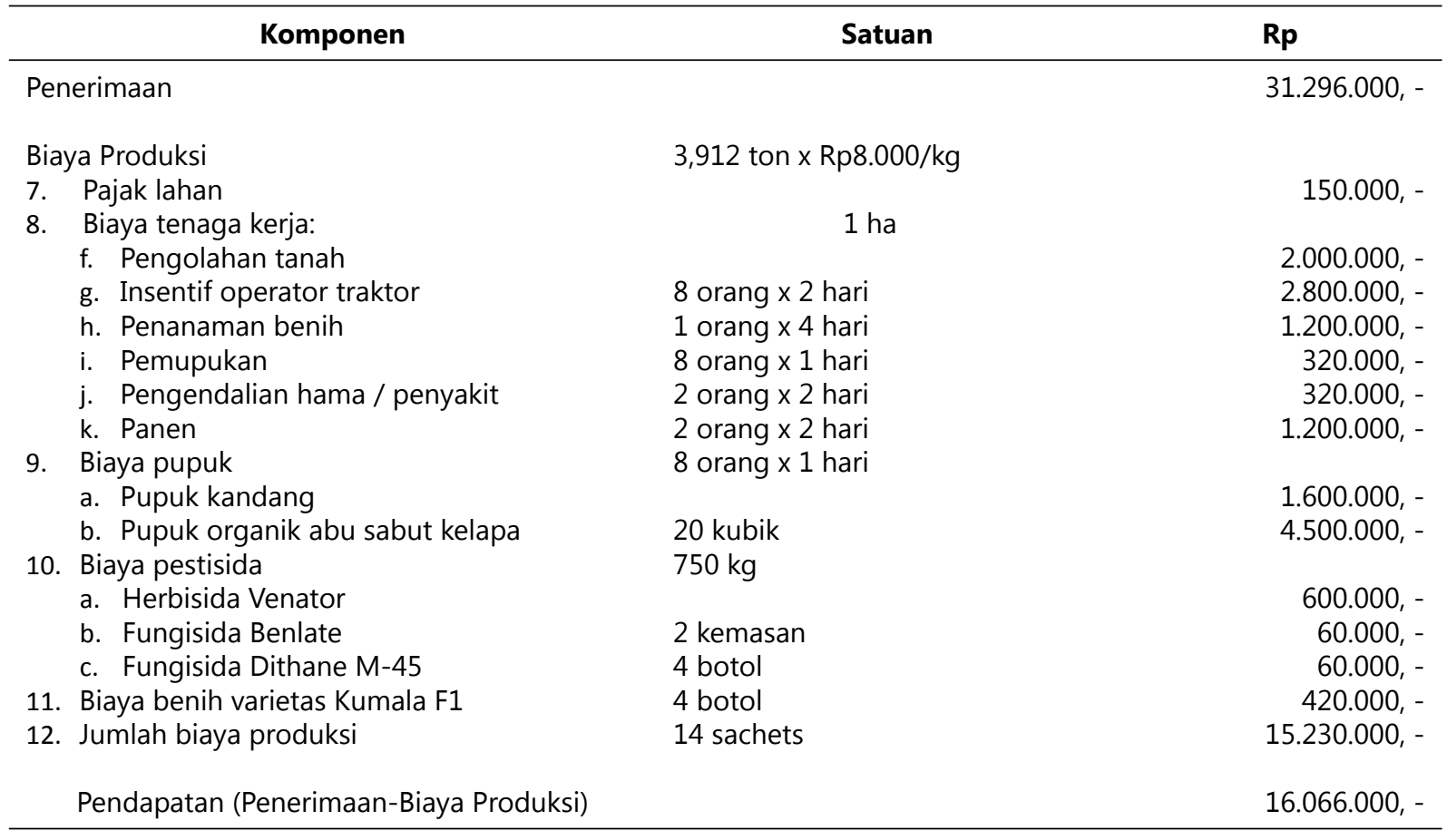

\section{Respons Mitra terhadap Pelaksanaan Kegiatan}

Berdasarkan evaluasi akhir pelaksanaan kegiatan, diperoleh tingkat kepuasan mitra yang cukup tinggi terhadap kerja sama dan keluaran (outcome) kegiatan pada usaha produktif mitra. Hal ini terutama dikarenakan adanya peningkatan produksi dan pendapatan usaha tani yang cukup signifikan melalui penerapan teknologi pemupukan sebagai solusi atas permasalahan yang dihadapi oleh mitra. Selain itu mitra juga merasa puas atas pendampingan yang diberikan oleh tim abdimas selama pelaksanaan kegiatan karena transfer pengetahuan, keterampilan, dan informasi yang diterima mitra yang bermanfaat untuk kelanjutan usaha tani jagung pulut yang dikelolanya. Tingkat kepuasan ini diharapkan dapat menjadi pendorong bagi mitra untuk terus melanjutkan adopsi teknologi ini pada kegiatan-kegiatan usaha tani selanjutnya.

Kegiatan pengabdian kepada masyarakat ini juga diharapkan dapat mempengaruhi sikap, pola pikir, dan motivasi mitra untuk mempraktikkan pengetahuan yang telah diperoleh di lapangan (Oja \& Lamalewa, 2017). Dengan demikian, maka usaha tani jagung pulut yang dikelola oleh mitra dapat dikembangkan menjadi lebih produktif dan menguntungkan secara ekonomis.

\section{SIMPULAN DAN SARAN}

\section{Simpulan}

Pelaksanaan kegiatan pengabdian masyarakat pada petani di Desa Buyumondoli, Kecamatan Pamona Puselemba, Kabupaten Poso telah memberikan peningkatan terhadap capaian teknis dan 


\section{Peningkatan Produksi dan Pendapatan Petani Jagung Pulut melalui Aplikasi Pupuk Organik Abu Sabut Kelapa \\ Marianne Reynelda Mamondol, Silvany Annatje Taariwuan}

ekonomis usahatani jagung pulut milik mitra kegiatan. Peningkatan produksi jagung pulut yang diperoleh ialah dari 0,90 ton/ha menjadi 3,912 ton/ha, sedangkan peningkatan pendapatan usaha tani ialah dari Rp2.600.000/ha/musim tanam menjadi sebesar Rp16.066.000/ha/musim tanam. Tingkat kepuasan mitra yang cukup tinggi terhadap kerja sama dan keluaran (outcome) kegiatan pada usaha produktif mitra merupakan pendorong bagi mitra untuk melanjutkan adopsi teknologi pemupukan organik abu sabut kelapa pada kegiatan-kegiatan usaha tani jagung pulut selanjutnya.

\section{Saran}

Kegiatan pengabdian ini masih memiliki keterbatasan berupa teknik pembakaran abu sabut kelapa yang sederhana, sehingga menghasilkan asap hasil pembakaran yang dapat menyebabkan gangguan pada lingkungan sekitar. Pengabdi selanjutnya dapat mendesain metode pembakaran abu sabut kelapa yang bersifat tertutup sehingga lebih ramah lingkungan.

\section{Ucapan Terima Kasih}

Terima kasih disampaikan kepada Direktorat Riset dan Pengabdian Masyarakat (DRPM) Direktorat Jenderal Riset dan Pengembangan Kementerian Riset, Teknologi, dan Pendidikan Tinggi atas pembiayaan kegiatan pengabdian kepada masyarakat ini melalui skema Program Kemitraan Masyarakat Stimulus (PKMS) Tahun 2019.

\section{DAFTAR PUSTAKA}

BPS Poso. (2013). Kabupaten Poso Dalam Angka 2012. Poso: BPS Poso.

Bunyamin, Z., Tabri, F., \& Akil, M. (2015). Pengelolaan hara untuk tanaman jagung hibrida pada lahan kering di Kabupaten Gowa. Prosiding Seminar Nasional Serealia, 306-312.

Dahlan, D., Salman, S., \& Wahab, A. (2013). Analisis pemasaran jagung pulut (Waxy Corn) di Desa Pakatto Kecamatan Bontomarannu Kabupaten Gowa. Jurnal Agrisistem, 9(1), 67-76.

Dulur, N. W. D., Wangiyana, W., Kusnarta, I. G. M., \& Farida, N. (2019). Pertumbuhan dan hasil tanaman jagung ketan tanpa olah tanah tugal langsung pasca padi konvensional dan sistem aerobik tumpangsari kacang tanah. Jurnal Agroteksos, 29(2), 90-96.

https://doi.org/https://doi.org/10.29303/agroteksos.v29i2.443

Juhaeti, T., Hidayati, N., \& Rahmansyah, M. (2013). Pertumbuhan dan produksi jagung pulut lokal Sulawesi Selatan yang ditanam di polibag pada berbagai kombinasi perlakuan pupuk organik. Jurnal Biologi Indonesia, 9(2), 219-232. https://doi.org/10.14203/jbi.v9i2.168

Maesaroh, S., Sedyawati, S. M. R., \& Mahatmanti, F. W. (2014). Pembuatan pupuk K2SO4 dari abu serabut kelapa dan air kawah item. Indonesian Journal of Chemical Science, 3(3), 239-243.

Malawat, S. (2015). Beberapa varietas jagung lokal dan prospek pengembangan produk olahannya di Kabupaten Maluku Tenggara Barat. Seminar Nasional Serealia, 533-543. 
ABDIMAS: Jurnal Pengabdian Masyarakat Universitas Merdeka Malang Volume 6, No. 1, February 2021: 121-132

Mamondol, M. R., \& Bunga, N. I. (2017). Peningkatan hasil dan kualitas jagung pulut melalui penggunaan pupuk abu sabut kelapa. Jurnal Adiwidia, 4(1), 19-31.

https://doi.org/https://doi.org/10.31227/osf.io/qtc32

Maruapey, A., \& Faesal, F. (2010). Pengaruh pemberian pupuk kcl terhadap pertumbuhan dan hasil jagung pulut ( Zea mays ceratina . L ). Prosiding Pekan Serealia Nasional, 315-326.

Muchtar, M., Febrianti, T., Irmadamayanti, A., \& Muharni, M. (2018). Pengaruh implementasi sistem irigasi sprinkler, kompos, dan biochar terhadap pertumbuhan dan hasil jagung pulut di lahan kering Kabupaten Sigi, Sulawesi Tengah. Seminar Nasional Peran Keanekaragaman Hayati Untuk Mendukung Indonesia sebagai Lumbung Pangan Dunia, 51-59.

Nurhayati, N., Jamil, A., \& Anggraini, R. S. (2011). Potensi limbah pertanian sebagai pupuk organik lokal di lahan kering dataran rendah iklim basah. Iptek Tanaman Pangan, 6(2), 193-202.

Oja, H., \& Lamalewa, F. (2017). Pemberdayaan Masyarakat Petani Jagung Berbasis Kelompok Usaha Tani dalam Meningkatkan Usaha Ekonomi Produktif (UEP) ddi Kampung Marga Mulia, Kabupaten Merauke. Societas: Jurnal Ilmu Administrasi dan Sosial, 6(2), 78-88.

https://doi.org/https://doi.org/10.35724/sjias.v6i2.660

Rizki, U., \& Agustini, R. (2018). Pengaruh konsentrasi abu sabut kelapa dengan penambahan biofertilizer terhadap serapan kalium pada tanaman cabai rawit (Capsicum frutescens L.). UNESA Journal of Chemistry, 7(2), 48-52.

Saprianto, B., Wahyudi, \& Seprido. (2021). Pengaruh waktu aplikasi pupuk NPK Phonska terhadap pertumbuhan dan produksi jagung pulut (Zea mays ceratina). Green Swarnadwipa: Jurnal Pengembangan Ilmu Pertanian, 10(1), 85-94.

Setyowati, N., \& Utami, N. W. (2013). Pengaruh jarak tanam terhadap pertumbuhan dan produksi tiga aksesi jagung pulut lokal maros. Jurnal Agrotropika, 18(1), 1-7.

Suarni, S. (2009). Komposisi nutrisi jagung menuju hidup sehat. Prosiding Seminar Nasional Serelia, 60-68.

Suarni, S. (2013). Pengembangan pangan tradisional berbasis jagung mendukung diversifikasi pangan. Iptek Tanaman Pangan, 8(1), 39-47.

Suarni, S., Aqil, M., \& Subagio, H. (2019). Potensi pengembangan jagung pulut mendukung diversifikasi pangan. Jurnal Penelitian dan Pengembangan Pertanian, 38(1), 1-12. http://dx.doi.org/10.21082/jp3.v38n1.2019.p1-12

Tengah, J., Tumbelaka, S., \& Toding, M. M. (2017). Pertumbuhan dan produksi jagung pulut lokal (Zea mays ceratina Kulesh) pada beberapa dosis pupuk NPK. Cocos, 1(1).

Wawo, A. H., Lestari, P., \& Setyowati, N. (2019). Eksplorasi jagung lokal di Sulawesi Selatan dan studi pertumbuhannya di Kebun Penelitian Puslit Biologi, LIPI, Cibinong. Biota: Jurnal Ilmiah IlmuIlmu Hayati, 4(2), 79-93. https://doi.org/10.24002/biota.v4i2.2474 